\title{
Disruption, dissolution and reconstruction: A dialectical view on inter-organizational relationship development
}

\begin{abstract}
This paper contributes to research on inter-organizational relationship dynamics by applying a dialectical approach. We analyze a situation where the relationship parties have divergent understandings of business exchange, and use a longitudinal, in-depth single case study method to investigate their interaction process. The case study focuses on the relationship between a customer and a supplier in the ferrochrome industry, using the acquisition of the supplier as the trigger of the relationship change process. The paper contributes to studies on relationship dynamics by showing how dynamics of inter-organizational relationships may result from struggles when parties' interests and goals do not align with existing relationship arrangements. In particular, we focus on the process of (re)construction of the relationship and its linkage to the structural properties of the relationship.
\end{abstract}

\section{Introduction}

Knowledge of relationship dynamics has become vital for business management (Payne \& Frow, 2005; Teece et al., 1997). New relationships are formed, and old relationships change, when multinational companies reach for foreign-controlled assets through joint ventures and acquisitions (Zander et al., 2012), and when global production networks integrate firms into interdependent structures that blur traditional geographical and organizational boundaries (Dicken, 2015). Through these relationship formations, different cultures, sets of values, and attitudes are brought together, and companies become exposed to settings with different structures, routines, and management styles than the ones they are accustomed to (Ghemawat, 2007; Madhok \& Keyhani, 2012). As a result, problems of understanding in inter-organizational cooperation are aggravated, leading participants in such relationships to develop distinct interpretations and understandings of the same phenomena (Porac, et al. 2002; Vaara, 2003).

To engage in interaction processes, which are imperative for collective action, participants have to fuse their divergent perspectives to some extent while sustaining the uniqueness of their 
individual perspectives (Baxter, 2004). An inter-organizational relationship thus represents a setting that is rife with tensions, accruing from simultaneous existence of contradictory forces. This raises the question of how the divergent understanding of participants affects the course of relationship development. In this paper, we argue, in line with literature on relational dialectics (Baxter, 2004; Baxter \& Montgomery, 1998), that the patterns of interactions between engaged parties set up relational-level dialectics that must be negotiated and dealt with by joint actions of both parties.

Much has been written about the dynamics of inter-organizational relationships. According to Vlaar et al. (2006) the majority of research in this area has revolved around issues of coordination, control and legitimacy, although inter-organizational relationships also entail "problems of understanding", originating from the differences between cooperating parties (Vlaar et al., 2006; Lewis et al., 2010). Akin to the calls for dialectic perspectives on interorganizational cooperation (e.g. Das \& Teng, 2000; De Rond \& Bouchiki, 2004; Vlaar et al., 2006; 2007; Smith et al., 2010), our aim is to explore how participants' divergent understandings of the relationship influence interaction, and consequently, development of the socially constructed relationship. Our contribution lies in showing how dynamics of interorganizational relationships may result from struggles between the parties when their views and aims concerning relationship arrangements diverge or converge over time. Relational arrangements refer to quasi-organizational properties of relationships such as resource structures, investments, mundane routines, and habituated action patterns (Harrison, 2004; Mattsson \& Johanson, 1992). In particular, we focus on the process of (re)construction (including individual perceptions and interactions between the parties) of the relationship and its linkage to the structural properties of the relationship.

We illustrate the relationship development process with a longitudinal case study of a customer-supplier relationship and focus on the dynamics that occurred after the customer was 
acquired by a third party. This acquisition led to a number of radical changes in the focal relationship. In this setting, the study addresses how the participants engage in maintaining, dissolving, and reconstructing the relationship. By emphasizing the conditions under which the dynamics of relating between the two firms unfold, we can better understand how and why each party actively attempted to change arrangements that hindered their goals, how the relationship changed, and how the new relational arrangements were constructed.

\section{Inter-organizational relationship dynamics: An overview}

Over the last few decades, investigating development and change in inter-organizational relationships has been one of the central scholarly quests in different management fields, including strategic management and organization studies (Berends et al., 2011; Ring \& Van de Ven, 1994), industrial marketing (Anderson et al., 1998; Corsaro \& Snehota, 2012; Kragh \& Andersen, 2009), and entrepreneurship (Hite, 2005; Lingo \& O’Mahony, 2010; Ozcan \& Eizenhardt, 2009). Inter-organizational relationships describe a long-term orientated and longlasting exchange of (tangible and intangible) resources among two or more organizations (Håkansson \& Snehota, 1995; Van de Ven, 1976). As such, relationships have been conceptualized as quasi-organizational entities with distinctive structural features that create stability in terms of actors' behaviors and structured resources (Powell, 1990).

On reviewing the relevant literature, we see three salient properties of relationships that are often used to define them, namely, temporal orientation, interdependence, and formalization. Temporal orientation refers to relationships as semi-organizational entities (Powell, 1990; Van de Ven, 1976) that endure over time. As opposed to the short-term discrete transactions, these long-lasting, semi-permanent entities demand a long-term orientation so that more patience and commitment are exercised by the parties (Das \& Teng, 2000; Dwyer et al. 1987). Interdependence highlights the degree of adaptation between the counterparts, and its effect on 
their respective autonomy. Over time, actors in a relationship construct a complex array of interwoven ties of technology, knowledge, social relations, administrative routines, and legality between them (Hallen et al., 1991). As such, member organizations or their representatives take on specialized roles in the structure and develop behavioral expectations of each other's rights and obligations (Andersen et al., 2009; Anderson et al., 1998). Formalization refers to the degree to which an inter-organizational relationship is governed by rules and procedures, standardized organization, and information and communication processes (Bocconcelli, Snehota, \& Tunisini, 2006). Business relationships often show a low degree of formalization; formal contracts are common, but their role is usually limited (Dyer \& Singh, 1998; Harrison, 2004; Håkansson \& Snehota, 1995). Instead, informal mechanisms (such as trust and confidence) have been singled out as more effective for the development of relationships (e.g. Ring \& Van de Ven, 1992; Uzzi, 1997; Zaheer etal., 1998). These three properties of relationships are highly inter-related. Higher commitment over time implies a high degree of interdependence among the parties and, by corollary, a high degree of interdependence creates a higher structural complexity, which in turn demands a higher reliance on trust and mechanisms of informal governance.

At the same time, inter-organizational relationships are a dynamic phenomenon (Mitrega \& Pfajfar, 2015). Relational dynamics often stem from initiatives embarked upon at the organizational actor level where the actors construct and reconstruct the relationships through interaction (La Rocca et al., 2017). As interactions take place, relationships are constructed and either consolidated or re-examined and revised (Dyer and Singh, 1998; Mitrega \& Pfajfar, 2015). Recent studies show that for overcoming problematic situations in inter-organizational relationships, communication (or voicing) of the experienced problems is a key for potential reconciliation (Edvardsson \& Strandvik, 2009; Salo et al. 2009). By deciding to commit to a particular relationship, actors preclude other primary exchange partners who could otherwise 
provide similar benefits. Consequently, by developing trust and committing resources towards chosen partners, actors also make themselves vulnerable to their counterparts, and simultaneously, by gaining some control of the resources and capabilities of others, they need to relinquish some control themselves (Baxter \& Kleinaltenkamp, 2015; Harrison, 2004).

Nonetheless, intentions and actions at the organizational level are at the same time confronted with existing arrangements at the relationship level. Intrinsic to the process associated with the use of resources and performance of activities within relationships is the change to the organizations involved. Yet, the actors' interests are shaped and channeled by the forces of established arrangements. Thus, we argue that the reification of relationship as a quasiorganizational structure, which constrains actors by reinforcing a particular type of interaction, is opposing to the ongoing process of relationship construction.

In general, inter-organizational relationship dynamics is one of the most important and, yet, underdeveloped areas in management studies (Mitrega \& Pfajfar, 2015; Palmatier et al., 2013). Among those who have tackled the topic, several scholars have stressed the role of larger structure of relationships and how firms are dependent on and constrained by the relationships in which they are embedded (e.g. Halinen et al., 1999; Kim et al., 2006). The concepts of network position and role, for example, have been presented as equally important for understanding the impact of established structure on the processes of change in business networks (Anderson et al., 1998; Chou \& Zolkiewski, 2012). The result has been a relatively narrow conception of relationship development: while this view manages to escape a discussion on the role of agency, it tends to remain tightly bound to structure, and therefore, overlooks the processes through which agency actually constructs relationship structure. Mainela \& Puhakka (2008) demonstrate that it is both challenging and vital to capture the agency of actors, without discounting the structural forces at play. 
We claim that giving selective attention to either agential or structural features of relationships without considering the other one hinders investigations into the explanations of the emergence, dissolution and reconstruction of the relationships. So far, only few studies have discussed the micro processes and individuals' actions that cause change in relationships. Typically, such investigations analyze relationships that are going through problems, and note in particular the role that communication plays in influencing relationship developments (Edvardsson \& Strandvik, 2009; Salo et al. 2009). Indeed, mutuality within the relationship is important for managing conflicting as well as common interests (Harrison, 2004). However, the shortcoming of the abovementioned approaches become evident particularly on occasions that are characterized by pluralism, divergence of understandings and lack of mutuality, which in turn give rise to confrontation and conflicts among business actors (e.g. Andersen et al., 2009). On such occasions, a dialectical process perspective can be used to explain change in relationships (Van de Ven \& Poole, 1995; Weick \& Quinn, 1999).

\section{Towards a dialectic perspective on relationship development}

The dialectic perspective, being sensitive to the inherent tensions between the structural and processual aspects of relationships and focusing on the balance of power between opposing forces is particularly suitable for exploring the dynamics of relationship development. Drawn from the Hegel-Marx tradition, it predicts the collision of coexisting, but contradictory, relational forces to produce new order. Benson (1977, p. 3) describes a dialectical view as follows:

A dialectical view is fundamentally committed to the concept of process. The social world is in a continuous state of becoming - social arrangements which seem fixed and permanent are temporary, arbitrary patterns and any observable social pattern is regarded as one among many possibilities. Theoretical attention is focused upon the transformation through which one set of arrangements gives way to another. 
A "relating" organization is not an autonomous, performed entity; instead, organizations "become" in and through interaction with others (Baxter, 2004; Calori, 2002). In Baxter's (2004: 187) words, "coconstruction of selves happens in relating". That is to say, virtually all the organizational outcomes are interdependent with the resources and capabilities controlled by other organizations (Pfeffer \& Salancik, 1978). Yet, while relationships are constantly constructed by the actors, the actors' actions are restricted by the very structure they may wish to change (Sydow \& Windeler, 1998). As such, organizations are confronted with contradictory needs - to differentiate and to combine their resources, to reify relational arrangement and to continuously reconstruct those established arrangements. A relational level dialectic is thus manifested as a dynamic tension between inter-organizational activities and the need for the relationships to cohere as a collective system (Putnam, 2013; Sydow \& Windeler, 1998; Zeitz, 1980). Figure 1 illustrates this process.

\section{PLACE FIGURE 1 ABOUT HERE}

Dialectical tensions come to being through ongoing actions and interactions between parties engaged in a relationship and manifest themselves in daily interactions between parties (Putnam et al., 2016). On the one hand, the structural features of the relationships stress the importance of compliance with norms expressed as expectations (Ring \& Van de Ven, 1994). Organizations thus develop behavioral expectations of each other's rights and obligations (Van de Ven, 1976), for example, the expectation to behave cooperatively rather than opportunistically. Expectations can be seen as behavioral manifestations of the structural aspect of the relationship that constrain agents to act in ways that are in their own interests as well as those of their counterparts (Sydow \& Windeler, 1998). On the other hand, counterparts with diverse goals and interests purposefully enact and construct the existing structures through their actions (Nohria, 1992). In an ongoing performative and constructive effort through interaction, 
actors transform themselves, their products and services, and ultimately their relationships (Story et al., 2011).

In its essence, the dialectical perspective is about the balance of power between opposing forces. Organizations in the relationships compete for domination and control to ensure that their own objectives are achieved (Gadde et al., 2003). While each firm is gaining control of at least one part of its "environment", it also relinquishes some of its internal control (Anderson et al., 1994). The dialectical perspective reminds us that the existing relational arrangement is likely to be reconstructed and maintained by the dominant intentions and the aims that are shared throughout the network of relationships. This suggests that the likelihood that business actors become engaged in incremental and gradual change is higher than the fundamental and radical relational change (Halinen et al., 1999; Zeitz, 1980). As such, actors realize relational gains as they gradually deal with the tensions through joint-problem solving and adaptive behavior. In this vein, contradictions set limits on the possibility of change (Seo \& Creed, 2002). Therefore, it comes as no surprise that research on relationship changes has mostly been on incremental or gradual changes.

Nonetheless, the dialectical tensions typically surface and become experienced by the actors in episodes that cross old and new organizational interfaces (Putnam et al., 2016). Discontinuities in structures, contexts, routines, expectations and perceptual frameworks (Weick, 1995) can cause disruptions and problems of understanding in inter-organizational relationships, particularly in early stages of collaboration (Vlaar et al., 2006). In such occasions (e.g. change of ownership) organizational actors may become very purposeful and decisive for how change progresses (Havila \& Salmi, 2000). In other words, they are not simply captives of their role, but, while under stability they might follow established routines without any further consideration, sometimes they may become purposeful in trying to reach beyond the limits of 
the existing arrangement, in order to reconstruct the organization in accord with alternative concepts of its purposes (Benson, 1977; McCarthy \& Zald, 1977).

As previously explained, through interaction, actors try to develop a joint understanding of the business exchange, form their expectations in regard to future cooperation, and to align their actions appropriately. However, there is no reason to assume that the interests and goals of each actor are aligned with the existing arrangements in terms of counterpart's expectations. Insofar as there is a weak degree of misalignment among relationship participants' expectations and attitudes, conflicts are dealt with and solved through joint-problem solving and negotiation (Mohr \& Spekman, 1994). By solving these problems through adjusting and exploring changes, in turn, actors are able to gain benefits of relationships (Håkansson \& Snehota, 1995). In such situations, the relationships are reconstructed through a gradual transformation and reshaping of routines and structures. Yet, situations might arise in which the existing relational arrangements reflect and favor the goals of one side of a relationship, with little coordination and joint understandings between the participants. If the other party's expectations are not met, this may result in a 'critical time', that is, "a period of stress and raised sensitivity in a relationship that may change it" (Edvardsson \& Strandvik, 2009: p. 326; cf. Andersen et al., 2009). In such cases, where there is a lack of mutuality between parties, we expect major changes in the relational arrangements.

We use the conceptual framework presented in Figure 1 to explore the dynamics of interorganizational relationship development further in situations where divergence of understandings prevail and business relationships are rife with tension and confrontations. The outlined conceptual grounds will be of help when we set out to analyze the processes through which structural and agential forces come to play in such relationships, how and why over time some forces tend to dominate the relationship, and how relationships undergo transformation as the result of an interplay between conflicting forces. 


\section{Methods}

Our investigation of relationship dynamics and dialectics is based on a process research design (Langley et al. 2013), and we conducted a qualitative inquiry to attain the required depth and richness of empirical data and analysis. We rely on an embedded longitudinal approach (Pettigrew 1997), and our setting is a single in-depth case study.

\subsection{Research context and case selection}

We carried out a longitudinal investigation of the acquisition of a Swedish company (Vargön Alloys) by the Turkish Yildirim Group and the effects of this acquisition on the target company's customer relationships. This acquisition was by 2015 the largest investment ever made by a Turkish company in Sweden. Yildirim Group is one of the top ten fastest-growing Turkish industrial groups ( $\left.\mathrm{DEiK}^{1}, 2012\right)$. At the time of the acquisition in 2008, Vargön Alloys was one of Europe's largest producers of ferrochrome, and its customers were among the world's largest companies in the metal and mining industries. This friendly acquisition involved complex dynamics between the companies and related customers. Our study brings to light the tensions between an industrial supplier and buyer (in our case, the acquisition target and its Swedish customer) over a long period of time after the acquisition, which were caused by the fundamental differences in the partners' approach to business exchange.

Before the acquisition, four main customers (Sandvik, Arcelor Mittal, Outokumpu, and Vallourec) accounted for almost $80 \%$ of Vargön Alloys' total sales. They all reacted to the changes after the acquisition in a similar manner: they terminated their contracts and ended their exchange relationship with Vargön Alloys. We focus here on one relationship - the one between Vargön Alloys and Sandvik - for two main reasons. First, multiple informants within Vargön Alloys raised the issue of the relationship with Sandvik, indicating its importance and

\footnotetext{
${ }^{1}$ the Foreign Economic Relations Board of Turkey
} 
salience for both companies because of its share of the total sales and of the long history of the relationship. Second, after the acquisition, the relationship between Vargön Alloys and Sandvik experienced turbulence and frequent changes, of which some were radical. This fluctuation provided us with useful variation in temporal observations (Langley et al., 2013).

\subsection{Data Collection}

Our data collection draws on a contextual process study (Pettigrew, 1997). While our unit of analysis is the development process of an (embedded) dyadic relationship over time, our data pertain to both intra-unit/organizational level and industry/global level. The buyer-supplier relationship underwent a radical change after the supplier was acquired by a third party. In our investigation, we cover the relationship from both buyer and supplier point of views. Our empirical data comprise interviews with management teams as well as archival data. We trace the struggles and ups-and-downs of the exchange relationship between Vargön Alloys and Sandvik over a long period of time, looking at both the pre-acquisition period up until 2008, and developments thereafter. Our data collection started in 2013 with a retrospective approach, while we have collected real-time data from 2013 to 2015 . While retrospective interviews may be problematic (due to memory issues, for instance), we see that our later (real-time) interviews, several interviewees, as well as our collected secondary data increase the reliability of our data.

Semi-structured interviews served as the primary source of data. We conducted 15 interviews with both sides of the relationships, covering top management (the founders/ CEOs, executive vice presidents and division heads), middle management (heads of units and functional departments), lower management, and employees. All the interviews were held in English and they were transcribed verbatim shortly afterwards. The average duration of each interview was approximately one hour, with a range from 45 minutes to 3 hours.

The first round of interviews focused on the acquisition of the supplier and was conducted in 2013, with the key managers in the Yildirim Headquarters in Istanbul, Turkey and the CEO 
of Vargön Alloys in Sweden. The interviews at this stage were loosely structured, geared towards the motives of the acquisition, strategic changes and the consequent challenges and opportunities that the parties faced throughout the process. The questions covered the company's background, its expansions and sales strategies, and the impact of the acquisition on internal operation as well as on the relationships with main customers.

The second round of interviews was carried out in 2014 in Sweden with the acquired company's managerial team. This time the questions were more structured around pre- and post-acquisition changes regarding operational processes, relationships with business counterparts (suppliers and customers), and managers' approaches towards the market, drawing on the theoretical framework of the study (the dialectical approach). Our interview protocol also included a range of questions dealing with specific changes in the relationship with the customer: Sandvik. As each interview progressed, we began focusing on the nature of specific challenges and issues, focusing on "how" and "why" questions. During this process we also confirmed the data from the previous interviews and asked for possible clarification/corrections, which helped to guarantee construct validity (Lee, 1999). Moreover, we addressed the contextual factors that had been discovered from the analysis of the previous interview and archival data. These interviews provided us with the acquired company's perspective on the acquisition and its effects.

A third round of interviews was conducted in 2015 , when we followed up the relationship development between the two companies. At that time, we made interviews with the supplier as well as with the two purchasing managers at Sandvik who were responsible for the Vargön Alloys account at different times following the acquisition. These interviews helped us develop a truly dyadic perspective of this relationship. Interviews in this final round were structured around the process theory that had been developed during the research process. 
In order to have as much information about the acquisition and the involved companies as possible, archival data was also gathered. The companies' annual reports, internal reports, such as business strategies, progress reports, as well as industry reports were examined. Additional information from companies' websites, press releases, and industry analyses allowed us to triangulate our understanding of the relationship contexts and outcomes.

\subsection{Data Analysis}

We used an abductive analytical approach (Dubois \& Gadde, 2002), meaning that we continually improved our understanding of how change unfolded over time while we did the analyses. We developed our theoretical interpretations in conjunction with increasingly accurate mapping of the case through three stages (Gioia et al., 2013). The process of analysis was an iterative comparison of data, emerging categories and existing literature on the process theories, involving four stages.

\subsubsection{Stage I: Developing detailed descriptions}

Our goal was to construct a detailed and rich case study, incorporating various types of data to account for the context and to support multiple levels of analysis (Langley, 1999). Two primary insights emerged that guided our further analysis. First, the changes observed did not follow the conventional life-cycle of teleological processes (Van de Ven \& Poole, 1995; Langley et al., 2013), but rather they were the outcome of tensions between the different attitudes of the involved companies towards business exchange. The managers described the situation as complex as it was hard to distinguish between the "right" or "wrong" decisions and actions. Second, the apparent tensions persisted over time. The case was marked by a continuum of episodes, where certain tensions significantly influenced relationships in some periods, while they receded to the background in other periods. These insights into the tensions and their perseverance suggested two very different, even opposing, attitudes towards business exchange. 
This led us to conduct further analysis with a dialectic lens, to better understand how interorganizational relationships evolve in dynamic tension.

\subsubsection{Stage II: Identifying key events}

Next, we applied a temporal bracketing approach to structure the data. In doing so, we focused on the explicit indications of change in the relationship. We defined as critical events in the Vargön Alloys-Sandvik relationship development process the major or radical changes in their mutual contract. For example, a change in the volume or price in a long-term contract in 2012 was not considered to be a critical event, because the contract was replaced with another longterm contract. We identified four main episodes: period of long-term contract, period of "no relationship", period of no contract, and period of long-term contract, by discerning three critical events: radical change in contracts, termination of contract, and signing a new long-term contract. The objectivity of formal contracts and the consensus of both companies about the changes in the relationship increased the reliability of the event coding (Van de Ven, 2007). The main episodes are illustrated in Figure 2.

One of the advantages of this temporal "decomposition" was that it also permitted us to analyze how changing contexts influenced the events (Langley, 1999). In addition to our analysis of the relationship, we incorporated both industry/global and intra-unit/organizational levels into our contextual analysis. This provided us with a deeper understanding of how some issues and tensions operated within a relationship (triggering conditions), and how and why they persisted over a period of time. For instance, we were able to take into account the impact of increasing prices of chrome ore and the dominance of South African or Chinese companies in the global ferrochrome industry, as well as changes in managerial positions and Yildirim Group resources. 


\subsubsection{Stage III: Identifying key sources of tensions and building a theoretical process}

framework

In parallel with the previous stage, we also coded the data, focusing on the discrete episodes and transitions from one episode to another. The purpose of this was to develop a process theory that went beyond a surface description, to penetrate the logic behind observed temporal progressions (Van de Ven, 2007). We read the data, asking: What is the underlying source of tensions in the relationships? How and why does the relationship go through the changes? We thus aimed for identifying specific processual mechanisms recurring over time (Langley et al., 2013). The narrative revealed the constant tension between exchange attitudes and expectations of the counterparts that persisted over time. We identified and coded three pairs of polarities, reflecting the conceptualization of inter-organizational relationships in the literature that were salient throughout the narrative, namely degree of formalization, temporal orientation, and degree of interdependence. However, even though the polarities were theoretically distinct, they did not reflect the actuality and inseparability of the contradictions. We therefore shifted our attention to the processes of interaction and relationship (re)construction. These processes were both seen as important by involved companies and offered a more compelling explanation of how changes occurred. Throughout the analytic process, we validated our findings by discussing them within our team, and we present direct quotations from the interviewees to increase transparency of our data and results.

Finally, we analyzed the relationship dynamics by looking at the misalignment between the existing/established relational arrangements with actors' interests and goals. We integrated data about the episodes of change, relationship contexts, and participants' attitudes and expectations. We started by focusing on the general pattern revealed by our case, which was 
constant tensions between two different, even opposing, attitudes. Change occurred when one of the opposing forces got out of balance and gained sufficient power or legitimacy to overthrow the contemporary status quo. We integrated existing theory in dialectic processes and our data to develop a processual understanding of how and why change unfolded over time.

\section{Case findings}

In the following narrative, we describe how tensions surfaced during different episodes, and how these tensions caused dynamics in the relationships depending on this specific context.

\subsection{Background: Vargön Alloy and its business}

Vargön Alloys $\mathrm{AB}$ was founded in 1874 and is one of the largest ferrochrome producers in Europe. Over the years, Vargön Alloys has developed an efficient method for producing ferrochrome using different raw material sources, something generally perceived as a significant technical challenge for the production process. On their supply side, chrome ore account for $62 \%$ of the total production cost, reflecting the dependence of Vargön Alloy on its suppliers and on chrome ore supply. Chrome and alloy ores were before the acquisition supplied from almost all over the world. The combination of technical expertise and long-term relationships with its suppliers had been Vargön Alloys' main recipe for a well-functioning production.

Vargön Alloys' products were mainly used in the steel industry: the low-phosphorus products for oil and gas pipes and the low-titanium products for ball-bearing steel. The company was primarily following a customer-oriented strategy, meaning that it limited the number of customers, but also tried to account for at least $20 \%$ of each of customer's purchases in order to be important for the customer. The four main customers accounted for $80 \%$ of the sales, and the relationships with all four were described as trust-based and informal. By choosing a strategy of supplying the geographically closest customers, Vargön Alloys could both provide 
a better price than the global competitors (through lower freight costs), and maintain close customer relationships. Problem solving and "being there" for its customers were part of Vargön Alloys strategic approach for ensuring sustainable sales, which was needed to break even and keep all the furnaces in operation.

Sandvik, one of the larger customers of Vargön Alloys, used low-phosphorus ferrochrome products in its operations. In order to address Sandvik's needs, Vargön Alloys and Sandvik together had investigated different mines around the world in order to find a good coke source, and to develop the low-phosphorus products they needed. This cooperation was described as the starting point of an extension in the product portfolio.

\subsection{Episode 1: Stable relationship and long-term contract}

The relationship between Sandvik and Vargön Alloys was before the acquisition marked by interdependent business cooperation. The cooperative attitude toward the relationship was mutual, as managers in Sandvik too considered product quality, as well as the supplier's focus on health and environment and long-term thinking as critical for supporting the company in its development of niche products. The close relationship with Sandvik concerned not only joint product development, but also areas such as logistics, payment arrangements, quality control, and raw material purchases.

Even though there were formal contracts between the two companies, all terms were discussed informally whenever needed, to satisfy both parties in terms of, e.g., volumes of sale and purchases, quality, and profit. Although the price for products was discussed at the beginning of each year, this aspect was definitely not the major element of effective relationship coordination. Managers in both Vargön Alloys and Sandvik emphasized the importance of close, direct, frequent, and informal "face-to-face" interaction, from top managers to technical operators. 


\subsubsection{Transition to episode 2}

In 2007, the four owners of Vargön Alloys met to discuss offers they had received from potential buyers of the plant. At that point, selling Vargön Alloys had become an option and they had approached their contacts on this matter. The owners had bought the plant from an American company in the 1980s and expected to own it only for few years. However, 20 years later they found themselves still in charge of the 300-employee strong company. In 2007, they started to worry despite their strong position in the European market as they saw that the industry was changing quickly: increasing demands from stronger Chinese businesses were raising the prices of chrome ore.

In the other part of Europe, the family owned, and fast-growing, business conglomerate Yildirim Group was struggling with challenges of its own. Rooted in the agricultural sector, the group had begun its business with imports and exports in the 1960s. Starting with the privatization movement in Turkey in the late 1990s and early 2000s, the group later broadened its operations into several subsidiaries, and evolved into a globally and industrially diversified conglomerate of companies operating in ten different industries.

In 2004, the group had acquired the state-owned company EtiKrom for USD 58 million. EtiKrom had belonged to Eti Holding, which was the owner of the mining assets in Turkey. At the time Yildirim Group had no former experience in the chrome industry, but in three years two furnaces were opened. At the time of the acquisition of Vargön Alloys, EtiKrom had reached a production of 50 thousand tons of ferrochrome per year and owned 79 chrome ore mines in Turkey, leaving them with a large excess of chrome ore that it had to sell to third parties. At the time, Eastern China was the largest market in the world where to sell metallurgical grade chrome ore. Yildirim Group was vulnerable to the uncertain and monopolistic behavior of Chinese ore buyers. One the other hand, Yildirim was selling its 
ferrochrome production mainly to the European market, where Vargön Alloys was considered to be the largest competitor. Vargön Alloy's superior quality and low prices had been giving Yildirim Group a headache for some time.

Therefore, in 2008, a deal was settled, and the group acquired Vargön Alloys as its first international acquisition for the deal value of 100 million USD. This made Yildirim Group (through EtiKrom) the world's second largest producer of high-quality high-carbon ferrochrome. By acquiring Vargön Alloys, Yildirim managed to not only "get rid of” its largest competitor in the European market, but also to utilize its excess of raw material, thanks to Vargön Alloys production capacity, and to amend its dependence on China.

\subsection{Episode 2: A new Vargön Alloys, changes in contracts}

From the very first moments after the acquisition, the Swedish managerial team of Vargön Alloys realized that the approach of the new owners in running the business was different from what they were used to. The company made dramatic changes in several aspects of the business. The first changes unsurprisingly happened in the supplier base. After the acquisition, the company got $100 \%$ of its ore and coke from its sister company EtiKrom in Turkey, where they had central sourcing for coke. Electricity and some minor materials were still sourced from local suppliers. The new owners brought their new market strategy to the table, relying on highquality and stable supply base in Turkey, large combined production capacity, and lower cost of transportation in comparison to previous years. Thus, they changed from the bulk products for making stainless-steel into products with higher chromium, used for special-steel products, although the market for special-steel is much smaller than the stainless-steel market. Moreover, due to the low profit margin of bulk products, the company decided to shut down one of the furnaces. 
Following the new strategy, Vargön Alloys managed to develop products that have sulfur content below the European standard, while still having low phosphorus content. As a result, as the CEO said, "suddenly the global market emerged." At the same time, given recent changes in the global ferrochrome industry and the increasing price for chrome ore, the company decided to increase its prices, based on South African benchmarks. For this reason, the new owners started re-negotiating all the existing contracts with established customers immediately after the acquisition.

All the major customers, including Sandvik, were upset by Vargön Alloys' disregard of established contracts, and these antagonist changes were perceived as signs of an "arrogant" behavior that disregarded their needs and expectations. Eventually, shortly after the renegotiation of the contracts in early 2009, all customers reacted to the new approach of Vargön Alloys and decided to terminate their contracts. For a couple of years afterwards, no business was transacted between Vargön Alloys and Sandvik. Indeed, the misalignment in expectations caused a "huge drop" for Vargön Alloys, because not only Sandvik, but all four major customers of the company reacted similarly. Table 1 illustrates, with the help of exemplar quotes from the interviews, how the relationship status changed between episodes.

\subsubsection{Transition to episode 3}

The global financial crisis at the end of 2008 lead to a dramatic collapse in the demand for stainless steel. For more than three years, the average prices of chrome ore and ferrochrome continually decreased. At the same time, competition became fierce, because China increased its ferrochrome production, relying almost entirely on imported chrome ore. The Chinese companies however moved towards low grade, cheaper chrome ore, in comparison with the grade and price of Yildirim Group's chrome ore mines. 
During this period, Vargön Alloys still had strong financial support from its mother company, but Yildirim Group, with its large chrome ore resources in Turkey, had to cope with the global decline in demand. Building on the quality of the material and the recent changes in the global landscape, the company followed its original strategy upon the acquisition, namely an in-group exploitation of its excess chrome ore production. However, due to the loss of its major customers, Vargön Alloys faced a huge drop in total sales, from 65,000 ton in 2008, to less than 16,000 ton in 2009.

\subsection{Episode 3: No business, terminated contracts}

During this episode of almost two years, there was no relationship between Vargön Alloys and Sandvik. The European market had previously accounted for almost $100 \%$ of Vargön Alloys' sales, but the company now shifted focus to high-end and premium products sold mainly in the North American and Japanese market. The weakened relationships to the old customers made this shift even more crucial. The company started to build its presence in North America through a number of warehouses and a logistics chain. EtiKrom was already in the North American and Japanese markets, although through traders, without direct sales to customers.

However, apart from a number of spot-sales, Vargön Alloys did not manage to penetrate the markets with stable and long-term sales. One manager in Sweden noted two main reasons for this: the slow and rather conservative behavior of Japanese companies concerning sales and the "price sensitivity" in the North American market in time of a financial crisis. Some of the managers believed that the change in marketing strategy, away from the company-owned agencies and toward using traders, was part of the problem.

Following the new approach and due to budget reductions, most of the marketing activities were now carried out through distance communication (i.e. the internet). The Swedish managers, however, believed that face-to-face interactions with customers, especially during 
rough times, such as this financial crisis, would have been important for creating trust and eventually more sales. In process industries, such as ferrochrome and ferrosilicon production, volume as well as continuity of the sales are critical factors for sustainable operation. From Vargön Alloy's perspective, the fact that the background of Yildirim Group was in trading was one of the main explanations for their behavior towards the market.

The shift in the marketing strategy and the issue of interaction with the customers over time was not the only change that occurred. New strategies regarding product quality and characteristics were also adopted, as the company shifted to premium high-grade ferrochrome. While this strategy may have been successful in opening up new markets, the managers soon realized that the new product portfolio was making it challenging for the company to run production efficiently. Because of shift, the volumes dropped significantly due to the smaller (niche) market.

As for Sandvik, during this period the company started to search for alternative suppliers and managed to find substitutes for both the bulk and special grades ferrochrome. At the end of 2010, the company made some purchases from Vargön Alloys again, although these purchases were merely spot-trades.

\subsubsection{Transition to episode 4}

When customer relationships began to deteriorate after the acquisition, the CEO, who had been with Vargön Alloys since 2002, used his personal contacts with the customers, together with his knowledge of all companies' interests, to pursue the directions they considered as the right ones. For instance, on occasions such as exhibitions or seminars he used every opportunity to contact the "former" customers and to create a new understanding between them and the new owner of Vargön Alloys. 
Several other individuals as well sought to reconstruct the relationship between Vargön Alloys and Sandvik. These included the purchasing manager of Sandvik, who sought to establish a concrete connection as a means of overcoming the difficulties in the relationship and transferred to Vargön Alloys, becoming their marketing manager in 2011. This meant a notable change: managers in both companies considered this a major step towards Vargön Alloys regaining Sandvik's trust and reviving the relationship between the companies.

The first business exchange between Sandvik and Vargön Alloys after the contract had been broken took place in 2010. This was afterwards referred to as "testing the waters." As was explained by one manager at Sandvik, this testing was done with the explicit purpose of determining whether Vargön Alloys would continue its transaction oriented behavior, or change its approach. At the end of 2011, the first long-term contract after the acquisition was signed between the two companies.

\subsection{Episode 4: Reviving relationships, a new contract}

Transformation from a "spot-seller" to a "long-term contract supplier" got underway in the new long-term contract between the Sandvik and Vargön Alloys. The contract in 2011 included a product range and volume that was less than Vargön Alloys wanted, and prices that were higher than Sandvik considered satisfactory. During this period, the relationship could be characterized by short-term reciprocal arrangements. Hence, despite the contract, Sandvik did not have trust in the relationship. Instead, the company took a cautious path in the sense that whenever Vargön Alloys proved to be "trustworthy", it regained some volume.

During this period, Sandvik attempted to safeguard itself against the short-term and independent strategic orientation of Vargön Alloys. For instance, while a supplier's strong financial capability is usually appreciated, given the history of the relationship, Sandvik considered the financial strength of Vargön Alloys to be a double-edged sword that could lead 
to unexpected turns in behavior. The trust of the old days was missing, so Sandvik kept alternatives open by diversifying its supply base and maintaining relationships with alternative suppliers. It also kept a closer eye on the behavior of Vargön Alloy.

A difference in expectations imprinted the relationship throughout this period. For instance, due to the high costs, Vargön Alloys closed down its in-house quality control, while Sandvik clearly considered the quality control to be an essential part of the relationship. Another change was a higher degree of formalization in communication and in handling disagreements and conflicts. For example, in dispute resolution, or in negotiating a change in agreements, at least three senior managers from each side were present on every occasion, something that would not have been needed before the acquisition.

In 2012, the contract was terminated by Sandvik and substituted with a new, mutually more beneficial, contract. The new contract included additional types of products, which could help Vargön Alloys to use its production capacity more efficiently. At the same time, the prices were lowered, which favored Sandvik.

This episode still indicates disagreements and tensions between the companies. For instance, in January 2013, Yildirim Group saw the future of the company to be in the production of premium quality ferrochrome and considered ferrosilicon production to have too low profit margins, and consequently, decided to close one furnace of Vargön Alloys. The operation manager in Vargön Alloys, in turn, believed that offering ferrosilicon as a complementary product to ferrochrome would have resulted in higher customer satisfaction in the long run. Some key customers, such as ArcelorMittal, even demanded to buy a year's worth of ferrosilicon in advance. A similar conflict was mentioned regarding Yildirim's purchase of "good-bargain" cheap coke, which resulted in decreased production efficiency due to the low quality of the raw material. 
Overall, however, in 2015 (seven years after the acquisition), the managers at Vargön Alloys remarked on a (slow) shift in the company's attitude towards the counterparts and customer relationships. Viewed from Sandvik's side, the acquisition and consequent process had long-term effects on the relationship, and the two companies are still not as tightly connected as they had been. Sandvik considered Vargön Alloys to be a potential long-term counterpart, but the past events still cast a shadow on their relationship.

\section{Discussion}

We began by asking how inter-organizational relationships are affected when participants have divergent understandings of the relationship. Our purpose has been to progress a perspective on inter-organizational relationship change that considers the inherent tension that stems from an ongoing struggle of the participants to simultaneously differentiate from and fuse with one another. The dialectic perspective acknowledges these opposing forces. It directs attention towards the diversities and inconsistencies inherent in relationships, which bring along a constant source of tensions and conflicts (Baxter, 2004; Montgomery \& Baxter, 2013).

In this section, we apply our conceptual framework (Figure 1) to the case findings. In doing so, we explore the dialectic dynamics of relationship change and how relationships undergo transformation as a result of an interplay between the opposing forces. Next, we explore the circumstances where these opposing forces are likely to surface and be experienced by the actors involved. Finally, we discuss the consequences of the tensions.

\subsection{Dynamics of Relationship Change}

We described relational dialectics as a constant confrontation of organizations with opposing needs. On the one hand, actors involved in a relationship need to combine resources and capabilities by utilizing and reifying existing relational arrangements. On the other hand, we 
observed that contextual forces such as changes in ownership and changes in global business landscape create challenges. As organizations struggle to cope with these challenges and respond to an ever-changing environment, they continuously have to reorganize the established arrangements. In circumstances, where the factors that can potentially interrupt the stability of the relationship are abundant, relationship development works in dynamic and dialectic tension, as illustrated in Figure 3. Our findings show that the participants were constantly wrestling with tensions resulted from frictions between their own interests and goals and the existing structural arrangements. Moreover, our case shows dialectic tensions between the interacting parties' goals and interests, which in turn caused disruptions in relationship arrangements.

\section{PLACE FIGURE 3 ABOUT HERE}

Our case illustrates the dialectic tensions that lie at the core of relationship change, and thus provides a deeper insight into understanding relationship stability and change. We show that tensions arise because of misalignment and deviation between the relational arrangements and the interests and goals of actors who construct the very arrangements through interaction processes. In this vein, any established arrangement is coupled with (changing) interests of the actors, and therefore, sow the seeds of their own decay - which gives rise to another period of change. That is to say, the reification of a relationship as a quasi-organizational structure constrains actions by reinforcing a particular type of interaction. In a pluralistic context, as the external environment changes, actors' interests and demands may change as well, and the actor whose demands are not met within the existing arrangement can turn into an agent of change.

Recently, a number of studies (e.g., Fang et al.,2011; Pressey and Vanharanta 2016) have addressed the notion of tension in relationships. Yet, most approaches have neglected the 
processes through which tensions surface, and the question of how and why relationships undergo change. In this study we have focused on the process through which a relationship between a pair of actors was disrupted, dissolved and reconstructed. A shift from a relationship (as the unit of analysis) to the pairs of actors that comprise the relationship opens up the possibility of incorporating diverse types of understandings and intentions of the parties involved, and of understanding the consequent structural relationship arrangements.

Although our findings are based on a single case, they have a conceptual form that suggest wider theoretical generalizability. We found that participants frequently struggled with functions and dysfunctions of formalization (e.g. Vlaar et al., 2007), short-term versus longterm orientation (Das \& Teng, 2000), as well as dependence and autonomy (Sydow \& Windeler, 1998). We, specifically, demonstrate how bringing these pairs of opposing forces to the fore can add to the conventional defining characteristics of inter-organizational relationships: the long-lasting, informal exchange of idiosyncratic resources between the interdependent counterparts. Instead of these stabilizing features, our study brings to the fore the dynamic interplay between the abovementioned polarities that lies at the core of the observed relationship change.

As shown in Figure 3, the relationship undergoes change as it is constantly oscillating between these polarities. The ongoing process of relationship changes between 2008 and 2015 was marked by episodes during which some tensions, such as favoring short-term gain over long-term benefits, were in the foreground and had significant influence on the interaction. Some tensions receded to the background at certain times, but surfaced during other periods. In certain periods, tension mounted between the actors' interests and goals and the existing relational arrangements, which led to loosening, and at one point halting, the relationship. On other occasions, tensions were resolved by means of negotiation and joint problem solving. In this context, the development and change of inter-organizational relationships was an intricate 
process driven by underlying dialectic tensions (Ford \& Ford, 1994; Van de Ven \& Poole, 1995).

\subsection{Context for Relationship Change}

As our findings suggest, wave after wave of interruptions in organizational, institutional and global contexts overwhelmed organizational actors' intentions and subsequent actions. Interruption refers to "any event, external or internal to the individual that prevents completion of some action, thought sequences, plan, or processing structure" (Mandler, 1982, p. 92), and it may concern inter-organizational relationships as well. . Therefore, the dynamic and dialectic tensions observed in our case may occur in other similar relational situations. In this section, we briefly explore three contextual factors namely, pluralism, resource availability and shared history, that seem to increase the likelihood of dialectic tensions to surface and be experienced by involved actors.

Our case illustrates complexities of the business environment, and due to current sociopolitical, technological and economic trends (such as, cross-border acquisitions, radical technological developments, and rise of new players in the global business landscape (Ford \& Mouzas, 2010; Dicken, 2015), we expect relationships to be more and more exposed to plurality and diversity. As the findings illustrate, pluralism can be interruptive and a reason why tensions surface and become salient. A pluralistic context is defined by divergence of interests and goals between parties involved in a relationship (Denis et al., 2011). Meyer \& Rowan (1977, cf. Sue \& Creed, 2002, p. 228) argue that organizations are embedded in a pluralistic context that is often permeated with "sharply inconsistent prescriptions of action, all supported by rationalized myths."

Resource availability is another factor that can disturb the balance between opposing forces. Our case illustrated that every period of alteration was marked with changes in the potential availability (or scarcity) of resources, such as financial resources, high-quality (in- 
house) raw material, target markets, and alternative customers/suppliers. As the alterations occurred, actors' perceptions of availability (or scarcity) of resources at each period affected their evaluation of the existing relational arrangement. An actor that finds the existing resource structures as an impediment to utilization of business opportunities and to persuasion of desired goals may turn into an agent of change (McCarthy \& Zald, 1977; Zeitz, 1980).

Finally, shared history (or lack of it) is another condition that we identified as a contributor to dialectic tensions. Our case shows that actors' goals and interests are constrained by the past, and this constraint, in turn, influence their future through shaping of expectations (Emirbayer \& Mische, 1998). Before the acquisition, through decades-long interaction, parties had established a set of relational arrangements and expectations that past patterns of behavior would repeat themselves in new interaction processes, allowing relationships to be sustained in a stable manner and reconstructed incrementally over time. However, while these expectations give a sense of predictability, stability and continuity to action (Schutz, 1967), they also create inertial forces that give rise to tensions in moments of interruption.

\subsection{Consequences of Disruption}

The impact of certain interruptive events and contextual factors on relationships depends on the configuration and balance of power between the opposing forces, i.e. structural and agential forces. Such events (e.g. changes of ownership, global financial crisis) can perturb a stable situation in which involved actors became conscious of the (constraints of) existing relational arrangements (Weick, 1995). The findings have revealed that an actor whose demands are not met by existing relational arrangements can turn into an agent of change. However, while interruptions can trigger relationship change, the direction of change depends on not only the intention of the actor who initiates the change, but also on the ability of the actor to pursue 
change in order to mobilize the available resources to exceed the established limits of the relationship and construct a viable alternative.

As shown here, a shift in relational arrangements often has some unintended consequences (MacKey \& Chia, 2013; Anderson et al., 2001). For example, in our case the negative reaction from the customer that eventually led to termination of the contracts was not intended. This is because a new arrangement emerges out of series of negotiation, bargaining and exercising power from both sides. Given this, as the lengthy process unfolds, the emerging arrangements most probably do not match the intentions of the change agent (Ellegaard \& Andersen, 2015), or the intentions of other connected parties (Anderson et al., 2001). The development of sufficient joint understandings is required to reconstruct the relationship.

In the face of opposing goals, a number of individuals in key positions strove to integrate divergent perspectives by offering consolidative suggestions that appeal to a diverse set of interests based on the prospects for mutual benefits in the relationships. This is in line with findings of (Ryan \& O’Malley, 2016) who emphasize the role of individuals as mediators between varying interests across organizations. We illustrate that the success of these attempts depends on connections with the past and retrospective rewriting of the relational arrangements — to rethink the past, reimagine the future, and recast issues as opportunities and reinterpret history using appreciative inquiry (Dutton, 1993; Weick \& Quinn, 1999, p. 379). In this vein, our findings contribute to a better understanding of the role of individuals and their capabilities in reconstructing inter-organizational relationships (Corsaro \& Snehota, 2012; Medlin \& Törnroos, 2015). Finally, our framework also accounted for conditions of dualistic struggles that became too unbalanced. Our case study allowed us to account for the situation where relationship participants have very different views of the relationship. We found that the relational crisis arising from tensions could potentially provide actors with a multiplicity of alternative logics. This in turn provides opportunities for relationship change and alternative 
arrangements that could fundamentally shift the composition of the relational arrangements. Our reasoning is shown in Figure 4 below.

In conclusion, our study shows that in addition to the inertia, incremental change and integrative forces that imprint relationship construction (as illustrated in Figure 1), we need to add friction, radical change and disruptions into our frames of relationship reconstruction (see also Halinen et al., 1998). As discussed, in the context of inter-organizational relationships, interruption can be caused by change in the factors endogenous (e.g. change of ownership) or exogenous (e.g. global financial crisis) to the relationship. However, it is not the mere fact of interruption that causes change. Rather, interruptions act as triggers that cause reactions in the actors (Alimadadi, 2016). Our study has pointed out how dialectic forces may cause friction, and consequently halting of relational arrangements and/or undermining of interaction between the parties. Consequently, as illustrated in Figure 4, we revise our initial framework by adding a potential disruptive path and the vicious cycle, which is caused by tension. The misalignment between parties create a path in which the relationship will lose strength, and the established arrangement will undermine this misalignment further, creating a need to reconstruct the relationship. 


\section{Conclusions}

The stability and change of relationships do not only depend on the interests and goals of the actors, nor can they be understood by merely analyzing the relationships as quasi-organizational forms. Hence, the present study, contributes to the understanding of how and why change unfolds by integrating the structural elements of relationships with actors' interests and goals. It gives weight to actors as agents of change and considers their role as a mediating mechanism between the relational contradictions and relationship change.

We started by asking how the divergent understandings of participants affect the course of relationship development. To address this question, grounded in relational dialectics, we viewed the interaction process in relationships as a dialectical tension of contradictory forces of action and structure, and stability and change. This view provides an alternative to "traditional" approaches to relationship development, which see relationships as enduring quasi-organizational entities and tend to stress re-enforcement of existing structures and aligned goals of the actors. The tensions we found consistently in our data deepen and expand understanding of inter-organizational relationship development as an ongoing dynamic and organic integration of dialectic tensions.

To engage in interaction that is imperative for collective action, participants form a unity while simultaneously sustaining the uniqueness of their perspectives (Baxter, 2004; Putnam et al., 2016). Our findings thus contribute to studies on dynamics of inter-organizational relationships by locating contradictions in the interaction processes between participants. Tracing the dynamic interplay between the participants' interests and established arrangements allowed us to go beyond merely identifying pairs of polarities, to unveil the complexity of contradictory forces that are inseparable and interdependent by nature. The analysis revealed how the opposing forces must be examined in their situated context, as contextual factors, such 
as pluralism, resource availability and shared history, are bound to cause dialectic tensions. This also explains why and how some forces gained power at certain points in time, while they receded to the background in other times.

Our study has important managerial implications as well. In particular, managers should note that any sets of new practices eventually sow seeds of decay; while they become reified and stabilized in relationship structures over time, another period of change is bound to follow. As Greiner (1972) illustrates, a major solution in one time could become a major liability later. By adopting only one type of practice, managers fall into disruptive path and vicious cycles of relationship change. Differentiating without integration fostered conflict, resulting in managers insisting on one type of arrangements and disregarding the alternatives (Smith, 2014). To achieve change with least unintended consequences, the critical task for management in each period of upheaval is to find a new set of practices and interaction routines that will become the basis for managing the next period of reification and incremental change.

Our empirical study centers around a cross-border acquisition, but we refer to this acquisition as an impulse for change, rather than aim at analyzing the acquisition or merger process itself. Yet, some of our results may also have valuable implications for future studies on mergers and acquisitions. By including the target organizations' connected relationships (Anderson et al., 2001), we bring to light the importance of the embedded features of the target that can directly influence business practices and the prospect of achieving synergy through unintended consequences of actions taken.

The case presented here has unique features, and indeed, it celebrates "the heterogeneity of actors, multiple logic and practice variation", something that according to Schneiberg and Lounsbury (2008) is a crucial ontological starting point for a new wave and new generation of business research (cf. Welch \& Piekkari, 2017). The ideas we present here are more generally applicable to cooperative business relationships. Yet, some relationships (i.e. the case at hand) 
appear to be even more complex and pluralistic than others. This exemplary case therefore provides us with aspects that are often hidden and hard to observe in more "typical" situations. We expect that similar patterns can be found in other cases of inter-organizational cooperation, especially those that have gone through discontinuities and/or those that are embedded in a pluralistic context. We thus urge scholars to conduct studies that allow for rich, contextual, and longitudinal analysis of inter-organizational relationships to take current understanding of dialectics forward. 


\section{References}

Alimadadi, S. (2016). Consistent Inconsistency: The Role of Tension in Explaining Change in Interorganizational Relationships, Doctoral dissertation, Department of Business Studies, Uppsala University.

Andersen, P. H., Christensen, P. R. \& Damgaard, T. (2009). Diverging expectations in buyerseller relationships: Institutional contexts and relationship norms. Industrial Marketing Management, 38/7: 814-824.

Anderson, H., Havila, V., Andersen, P., \& Halinen, A. (1998). Position and Role: Conceptualizing Dynamics in Business Networks. Scandinavian Journal of Management. 14: 167-186.

Anderson, H., Havila, V., \& Salmi, A. (2001). Can you buy a business relationship?: On the importance of customer and supplier relationships in acquisitions. Industrial Marketing Management, 30/7: 575-586.

Anderson, J. C., Håkansson, H., \& Johanson, J. (1994). Dyadic business relationships within a business network context. Journal of Marketing, 58/4: 1-15.

Baxter, L. A. (2004). A tale of two voices: Relational dialectics theory. Journal of Family Communication, 4/3-4: 181-192.

Baxter, L. A., \& Montgomery, B. M. (1998). A guide to dialectical approaches to studying personal relationships. In Dialectical approaches to studying personal relationships, Mahwah, N.J. : L. Erlbaum Associates, 1-15.

Baxter, R. \& Kleinaltenkamp, M. (2015). How relationship conditions affect suppliers' resource inputs. Australasian Marketing Journal, 23: 117-123.

Benson, K. J. (1977). Organizations: A dialectical view. Administrative science quarterly, 22/1: $1-21$

Berends, H., van Burg, E., \& van Raaij, E. M. (2011). Contacts and contracts: Cross-level network dynamics in the development of an aircraft material. Organization Science, 22/4: 940-960. 
Calori, R. (2002). Organizational development and the ontology of creative dialectical evolution. Organization, 9/1: 127-150.

Chou, H-H. \& Zolkiewski, J. (2012). Decoding network dynamics. Industrial Marketing Management. 41/2: 247-258.

Corsaro, D., \& Snehota, I. (2012). Perceptions of change in business relationships and networks. Industrial Marketing Management, 41(2): 270-286.

Das, T. K., \& Teng, B.-S. (2000). Instabilities of strategic alliances: An internal tensions perspective. Organization science, 11/1: 77-101.

Denis, J. L., Dompierre, G., Langley, A., \& Rouleau, L. (2011). Escalating indecision: Between reification and strategic ambiguity. Organization Science, 22(1), 225-244.

De Rond, M., \& Bouchikhi, H. (2004). On the dialectics of strategic alliances. Organization Science, 15/1: 56-69.

DEiK. (2012). Foreign Economic Relation Board. Retrieved from http://en.deik.org.tr/.

Dicken, P. (2015). Global shift: Mapping the changing contours of the world economy. . Guilford Publications.

Dubois, A., \& Gadde, L.-E. (2002). Systematic combining: an abductive approach to case research. Journal of Business Research, 55/7: 553-560.

Dwyer, F. R., Schurr, P. H., \& Oh, S. (1987). Developing buyer-seller relationships. Journal of Marketing, 51/2: 11-27.

Ellis, N., \& Ybema, S. (2010). Marketing identities: Shifting circles of identification in interorganizational relationships. Organization studies, 31/3: 279-305.

Fang, S. R., Chang, Y. S., \& Peng, Y. C. (2011). Dark side of relationships: A tensions-based view. Industrial Marketing Management, 40/5: 774-784.

Ford, J. D., \& Ford, L. W. (1994). Logics of identity, contradiction, and attraction in change. Academy of Management Review, 19/4: 756-785.

Ford, D., \& Mouzas, S. (2010). Networking under uncertainty: Concepts and research agenda. Industrial Marketing Management, 39/6: 956-962. 
Gadde, L.-E., Huemer, L., \& Håkansson, H. (2003). Strategizing in industrial networks. Industrial Marketing Management, 32/5: 357-364.

Ghemawat, P. (2007). Redefining global strategy. Boston: Harvard Business School Publishing.

Gioia, D. A., Corley, K. G., \& Hamilton, A. L. (2013). Seeking qualitative rigor in inductive research notes on the Gioia methodology. Organizational Research Methods, 16/1: $15-31$.

Greiner, L. E. (1972). Evolution and revolution as organizations grow. Harvard Business Review, 50/4: 37-46.

Halinen, A., Salmi, A. \& Havila, V. (1999). From dyadic change to changing business networks: an anlytical framework. Journal of Management Studies, 36/6, 779-794.

Harrison, D. (2004). Is a long-term business relationship an implied contract? Two views of relationship disengagement. Journal of Management Studies, 41/1: 107-125.

Havila, V., \& Salmi, A. (2000). Spread of change in business networks: An empirical study of mergers and acquisitions in the graphic industry. Journal of Strategic Marketing, 8/2: 105-119.

Hite, J. M. (2005). Evolutionary processes and paths of relationally embedded network ties in emerging entrepreneurial firms. Entrepreneurship theory and practice, 29/1: 113-144.

Håkansson, H., \& Snehota, I. (1995). Stability- and change- in business networks. In H. Håkansson, \& I. Snehota (Eds.), Developing Relationships in Business Networks. London: Routledge, 269-329.

Kim, T. Y., Oh, H., \& Swaminathan, A. (2006). Framing interorganizational network change: A network inertia perspective. Academy of management review, 31/3: 704-720.

Kragh, H., \& Andersen, P. H. (2009). Picture this: Managed change and resistance in business network settings. Industrial Marketing Management, 38/6: 641-653.

Langley, A. (1999). Strategies for theorizing from process data. Academy of Management review, 24/4: 691-710. 
Langley, A., Smallman, C., Tsoukas, H., \& Ven, A. H. (2013). Process studies of change in organization and management: unveiling temporality, activity, and flow. Academy of Management Journal, 56/1: 1-13.

La Rocca, A., Hoholm, T. \& Mork, B. E. (2017) Practice theory and the study of interaction in business relationships: Some methodological implications. Industrial Marketing Management, 60: 187-195.

Lee, T. W. (1999). Using qualitative methods in organizational research. Thousand Oaks, CA: Sage .

Lewis, L., Isbell, M. G., \& Koschmann, M. (2010). Collaborative tensions: Practitioners' experiences of inter-organizational relationships. Communication Monographs, 77/4: 460-479.

Lingo, E. L., \& O'Mahony, S. (2010). Nexus work: Brokerage on creative projects. Administrative Science Quarterly, 55/1: 47-81.

Madhok, A., \& Keyhani, M. (2012). Acquisitions as entrepreneurship: Asymmetries, opportunities, and the internationalization of multinationals from emerging economies. Global Strategy Journal, 2/1: 26-40.

Mainela, T., \& Puhakka, V. (2008). Embeddedness and networking as drivers in developing an international joint venture. Scandinavian Journal of Management, 24/1: 17-32.

Mattsson, L.-G., \& Johanson, J. (1992). Network positions and strategic action: an analytical framework. In G. Easton, \& B. Axelsson (Eds.), Industrial networks: a new view of reality. London: Routledge, 204-217.

McCarthy, J. D., \& Zald, M. N. (1977). Resource mobilization and social movements: A partial theory. American Journal of Sociology, 82/6: 1212-1241.

MacKay, R. B., \& Chia, R. (2013). Choice, chance, and unintended consequences in strategic change: A process understanding of the rise and fall of NorthCo Automotive. Academy of Management Journal, 56/1: 208-230.

Mandler, G. (1982). Stress and thought processes. In L. Goldberger, \& S. Breznitz (Eds.), Handbook of stress (pp. 88-104). New York: Free Press. 
Medlin, C. J., \& Törnroos, J. Å. (2015). Exploring and exploiting network relationships to commercialize technology: A biofuel case. Industrial Marketing Management, 49: 4252.

Meyer, J. W., \& Rowan, B. (1977). Institutionalized organizations: Formal structure as myth and ceremony. American journal of sociology, 83/2: 340-363.

Mitrega, M. \& Pfajfar, G. (2015). Business relationship process management as company dynamic capability improving relatioship portfolio. Industrial Marketing Management, 46: 193-203.

Mohr, J., \& Spekman, R. (1994). Characteristics of partnership success: partnership attributes, communication behavior, and conflict resolution techniques. Strategic management journal, 15/2: 135-152.

Montgomery, B. M., \& Baxter, L. A. (2013). Dialectical approaches to studying personal relationships. New York; London: Psychology Press.

Nohria, N. (1992). Is a network perspective a useful way of studying organizations? In N. Nohria, \& R. Eccles (Eds.), Networks and Organizations: Structure, Form, and Action. Boston, MA: Harvard Business School Press, 1-22.

Ozcan, P., \& Eisenhardt, K. M. (2009). Origin of alliance portfolios: Entrepreneurs, network strategies, and firm performance. Academy of Management Journal, 52/2: 246-279.

Palmatier, R. W., Houston, M.B., Dant, R.P. \& Grewal, D. (2013). Relationship velocity: Toward a theory of relationship dynamics. Journal of Marketing, 77/1: 1-49.

Payne, A. \& Frow, P. (2005). A strategic framework for customer relationship management. Journal of Marketing, 69/4: 167-176.

Pettigrew, A. M. (1997). What is a processual analysis? Scandinavian Journal of Management, 13/4: 337-348.

Pfeffer, J., \& Salancik, G. R. (1978 ). The External Control of Organizations: A Resource Dependence Perspective. New York: Harper and Row.

Porac, J., Ventresca, M., \& Mishina, Y. (2002). Inter-organizational cognition and interpretation. In The Blackwell Companion to Organizations. Wiley-Blackwell. 
Powell, W. W. (1990). Neither market nor hierarchy: Network forms of organization. Research in Organizational Behavior, 12: 295-336.

Putnam, L. L. (2013). Dialectics, contradictions, and the question of agency: A tribute to James R. Taylor. In Organization and Organizing (pp. 47-60). Routledge.

Putnam, L. L., Fairhurst, G. T., \& Banghart, S. (2016). Contradictions, dialectics, and paradoxes in organizations: A constitutive approach. Academy of Management Annals, 10/1: 65-171.

Pressey, A. D., \& Vanharanta, M. (2016). Dark network tensions and illicit forbearance: Exploring paradox and instability in illegal cartels. Industrial Marketing Management, 55: $35-49$.

Ring, P. S., \& Van de Ven, A. H. (1994). Developmental processes of cooperative interorganizational relationships. Academy of Management Review, 19/1: 90-118.

Ring, P. S., \& Van de Ven, A. H. (1992). Structuring cooperative relationships between organizations. Strategic Management Journal, 13/7: 483-498.

Ryan, A., \& O'Malley, L. (2016). The role of the boundary spanner in bringing about innovation in cross-sector partnerships. Scandinavian journal of management, 32/1: 19.

Salo, A., Tähtinen, J., \& Ulkuniemi, P. (2009) Twists and turns of triadic business relationship recovery. Industrial Marketing Management, 38/6: 618-632

Schneiberg, M., \& Lounsbury, M. (2008). Social movements and institutional analysis. In R. Greenwood, C. Oliver, R. Suddaby, \& K. Sahlin-Andersson (Eds.), The Sage handbook of organizational institutionalism. London: Sage, 650-672.

Schutz, A. (1967). The phenomenology of the social world. Northwestern University Press.

Seo, M.-G., \& Creed, W. D. (2002). Institutional contradictions, praxis, and institutional change: A dialectical perspective. Academy of Management Review, 27/2: 222-247.

Smith, W. K. (2014). Dynamic decision making: A model of senior leaders managing strategic paradoxes. Academy of Management Journal, 57/6: 1592-1623. 
Smith, W. K., Binns, A., \& Tushman, M. L. (2010). Complex business models: Managing strategic paradoxes simultaneously. Long range planning, 43/2-3: 448-461.

Story, V., O'Malley, L., \& Hart, S. (2011). Roles, role performance, and radical innovation competences. Industrial Marketing Management, 40/6: 952-966.

Seo, M. G., \& Creed, W. D. (2002). Institutional contradictions, praxis, and institutional change: A dialectical perspective. Academy of management review, 27/2: 222-247.

Sydow, J., \& Windeler, A. (1998). Organizing and evaluating interfirm networks: A structurationist perspective on network processes and effectiveness. Organization Science, 9/3: 265-284.

Teece, D.J., Pisaro, G. \& Shuen, A. (1997). Dynamic capabilities and strategic management. Strategic Mangement Journal, 18/7: 509-533.

Uzzi, B. (1997). Social Structure and Competition in Interfirm Networks: The Paradox of Embeddedness. Administrative Science Quarterly, 42/1: 35-67.

Vaara, E. (2003). Post-acquisition integration as sensemaking: glimpses of ambiguity, confusion, hypocrisy, and politicization. Journal of Management Studies, 40/4: 859894.

Van de Ven, A. H. (1976). On the nature, formation, and maintenance of relations among organizations. Academy of Management Review, 1/4: 24-36.

Van de Ven, A. H., \& Poole, M. S. (1995). Explaining development and change in organizations. Academy of Management Review, 20/3: 510-540.

Weick, K. E. (1995). Sensemaking in organizations. Thousand Oaks, CA: Sage.

Weick, K. E., \& Quinn, R. E. (1999). Organizational change and development. Annual Review of Psychology, 50/1: 361-386.

Welch, C. \& Piekkari, R. (2017). How should we (not) judge the 'quality' of qualitative research? A re-assessment of current evaluative criteria in International Business. Journal of World Business, 52/5: 714-725. 
Vlaar, P. W., Van den Bosch, F. A., \& Volberda, H. W. (2006). Coping with problems of understanding in inter-organizational relationships: Using formalization as a means to make sense. Organization Studies, 27/11: 1617-1638.

Vlaar, P. W., Van Den Bosch, F. A., \& Volberda, H. W. (2007). Towards a dialectic perspective on formalization in inter-organizational relationships: How alliance managers capitalize on the duality inherent in contracts, rules and procedures. Organization Studies, 28/4: 437-466.

Zander, U., Zander, L., \& Yildiz, E. (2012). Building competitive advantage in international acquisitions: grey box conditions, culture, status and meritocracy. In Handbook of Research on International Strategic Management. Edward Elgar, 211.

Zeitz, G. (1980). Inter-organizational dialectics. Administrative Science Quarterly, 25/1: 7288 
Table 1: Episodes of change: Exemplar quotes

\begin{tabular}{|c|c|c|}
\hline $\begin{array}{c}\text { Episode } \\
\text { time }\end{array}$ & $\begin{array}{c}\text { Relationship } \\
\text { status }\end{array}$ & Exemplar quotes \\
\hline $\begin{array}{l}\text { Episode } \\
1 \\
\text { Before } \\
2008\end{array}$ & $\begin{array}{l}\text { Stable } \\
\text { relationship / } \\
\text { Long-term } \\
\text { contract }\end{array}$ & $\begin{array}{l}\text { "We normally had long relations, we didn't have fixed and hard } \\
\text { contracts. We were able to sell this much to you next year and so } \\
\text { on! It was always the discussion and negotiations and then [one] } \\
\text { tries to fill the books here with material." (Former owner -Vargön } \\
\text { Alloys) } \\
\text { "They [the customers] knew us, so we were selling not truck loads } \\
\text { but } 100000-150000 \mathrm{~kg} \text { which would go to their operations } \\
\text { directly and they knew that they can trust us with everything. At } \\
\text { that time, they didn't run any sampling or analysis on our } \\
\text { products, we did it here and they trusted us." (Former owner- } \\
\text { Vargön Alloys) } \\
\text { "Sandvik generally has a long-term orientation strategy in regard to } \\
\text { its suppliers. And by that the company expects the suppliers to be } \\
\text { there for them and help them to mutually develop products } \\
\text { especially in the niche product range." (Manager, Sandvik) } \\
\text { "Sandvik was not the biggest customer for us, but they were } \\
\text { important in a way that when you are a sole supplier to } \\
\text { somebody, take big responsibility." (CEO - Vargön Alloys) } \\
\text { "We [Sandvik] were looking for a supplier that could help us develop } \\
\text { our products. One that was willing to listen to our requirements } \\
\text { and technical needs, and Vargön Alloy did that." }\end{array}$ \\
\hline $\begin{array}{l}\text { Episode } \\
2 \\
2008-09\end{array}$ & $\begin{array}{l}\text { New owner / } \\
\text { Changes in } \\
\text { contracts }\end{array}$ & $\begin{array}{l}\text { "There was a need to change. It was very clear and very direct. I } \\
\text { remember, what everybody here also remembers, that he [Robert } \\
\text { Yildirim] said: 'Okay, I bought this plant and if it doesn't work, I } \\
\text { lose some money, but you will lose your jobs.' So, you got to } \\
\text { change. And I think we have done that." (CEO - Vargön Alloys) } \\
\text { "The key is trust. We [Sandvik] had a contract that proved not to be } \\
\text { worth anything. They didn't really take into account our contract } \\
\text { and agreement." (Manager - Sandvik) } \\
\text { "It was another attitude, definitely another attitude. A little bit } \\
\text { arrogant I would say. You could also say that it was a new attitude } \\
\text { on the market because we had not heard it before. They wanted } \\
\text { higher prices, they were driving the prices. And the relation, okay } \\
\text { it could be there, but it was not necessary, and so on." (Marketing } \\
\text { manager - Vargön Alloys) }\end{array}$ \\
\hline
\end{tabular}




\begin{tabular}{|c|c|c|}
\hline $\begin{array}{l}\text { Episode } \\
3 \\
2009-11\end{array}$ & $\begin{array}{l}\text { No business / } \\
\text { Termination } \\
\text { of contracts } \\
\text { with existing } \\
\text { customers, } \\
\text { Searching } \\
\text { for new } \\
\text { opportunities }\end{array}$ & $\begin{array}{l}\text { "They have cut their [marketing department] wings so they are not } \\
\text { allowed to do as much as before. And they were selling almost } \\
\text { 100\% to Europe at that time. Now they are selling globally, but } \\
\text { suddenly we were selling everything to traders. So, they can't } \\
\text { control their end consumers. You also need to have relations with } \\
\text { the technical guys of the customer. I mean if you sell to a trader, } \\
\text { he's not selling a product. He's just selling a certain number of } \\
\text { kilos of [chrome] and he cares less because he is just cutting in- } \\
\text { between. That's the only interest he has." (Senior advisor- } \\
\text { Vargön Alloys) } \\
\text { "On the customer side [before the acquisition], we had a lot of } \\
\text { customers on the charge chrome, which is more of a bulk product, } \\
\text { and then Robert [Yildirim] wanted to go away from that and enter } \\
\text { more into the niche product, with the premium market. So we have } \\
\text { done that. The problem is, of course, to have the volume. And this } \\
\text { is a process industry, so our main concern right now is the } \\
\text { volume." (CEO - Vargön Alloys) }\end{array}$ \\
\hline $\begin{array}{l}\text { Episode } \\
4 \\
2011-15\end{array}$ & $\begin{array}{l}\text { Reviving } \\
\text { relationship / } \\
\text { A new } \\
\text { contract }\end{array}$ & $\begin{array}{l}\text { "We are still struggling with the differences in attitudes towards } \\
\text { production. For instance, Yildirim wanted to take away the quality } \\
\text { control due to its high cost, however we [Sandvik] argued that } \\
\text { that is actually the reason that the company buys its material from } \\
\text { Vargön Alloys, and that the quality control is the essential part of } \\
\text { the trustworthiness of Vargön Alloys." (Manager - Sandvik) } \\
\text { "You know; relationship is a huge part in the business. So, it is } \\
\text { something that you really need to work on, and of course } \\
\text { sometimes we wish our Turkish colleagues would have a better } \\
\text { understanding of. It seems now, I hope, that our customers } \\
\text { recognize us as more of less the old Vargön Alloys regarding } \\
\text { attitudes, the way to build relations and so on, so I think today it's } \\
\text { more or less back hopefully." (Manager - Vargön Alloys) }\end{array}$ \\
\hline
\end{tabular}


Figure 1 - The process of relationship construction

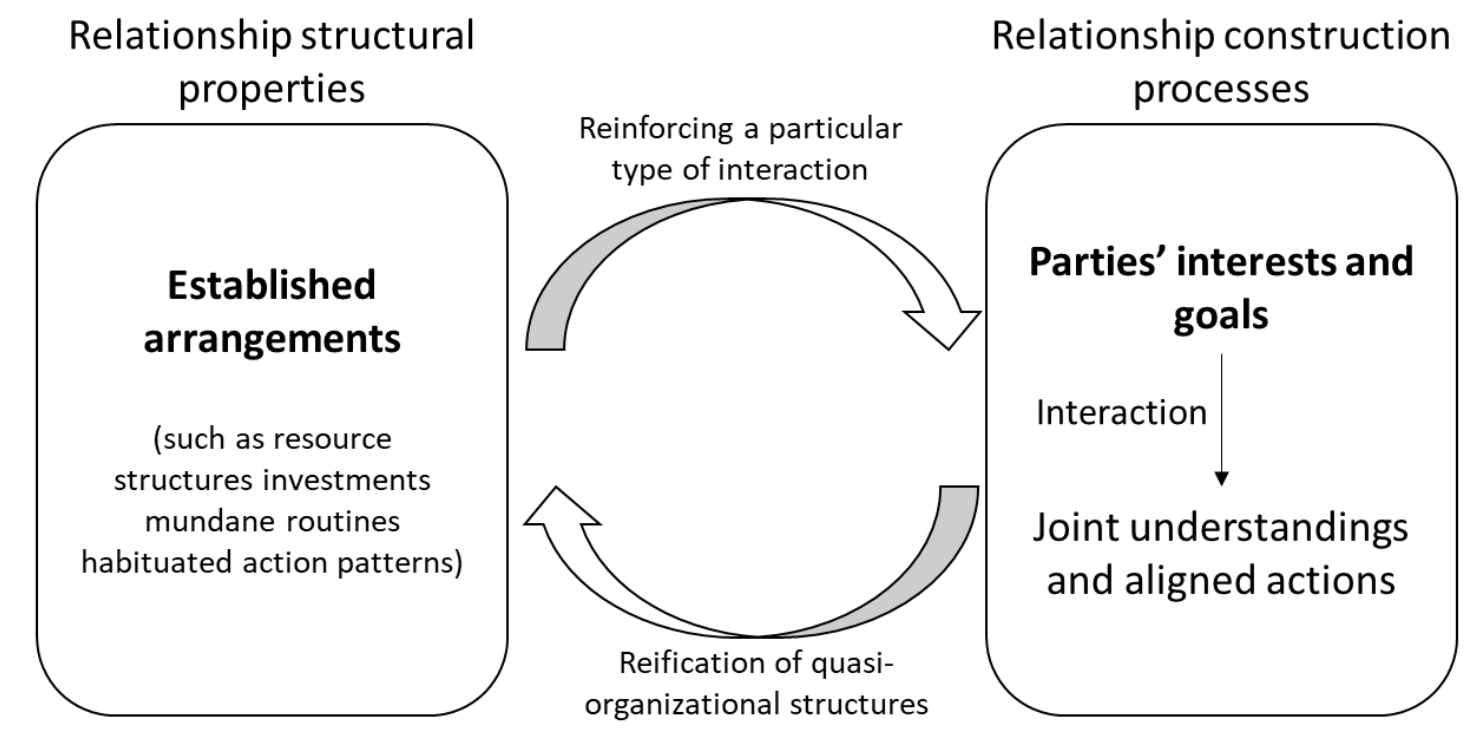

Figure 2 - Timeline of the development and change of the relationship between Vargön Alloys and Sandvik
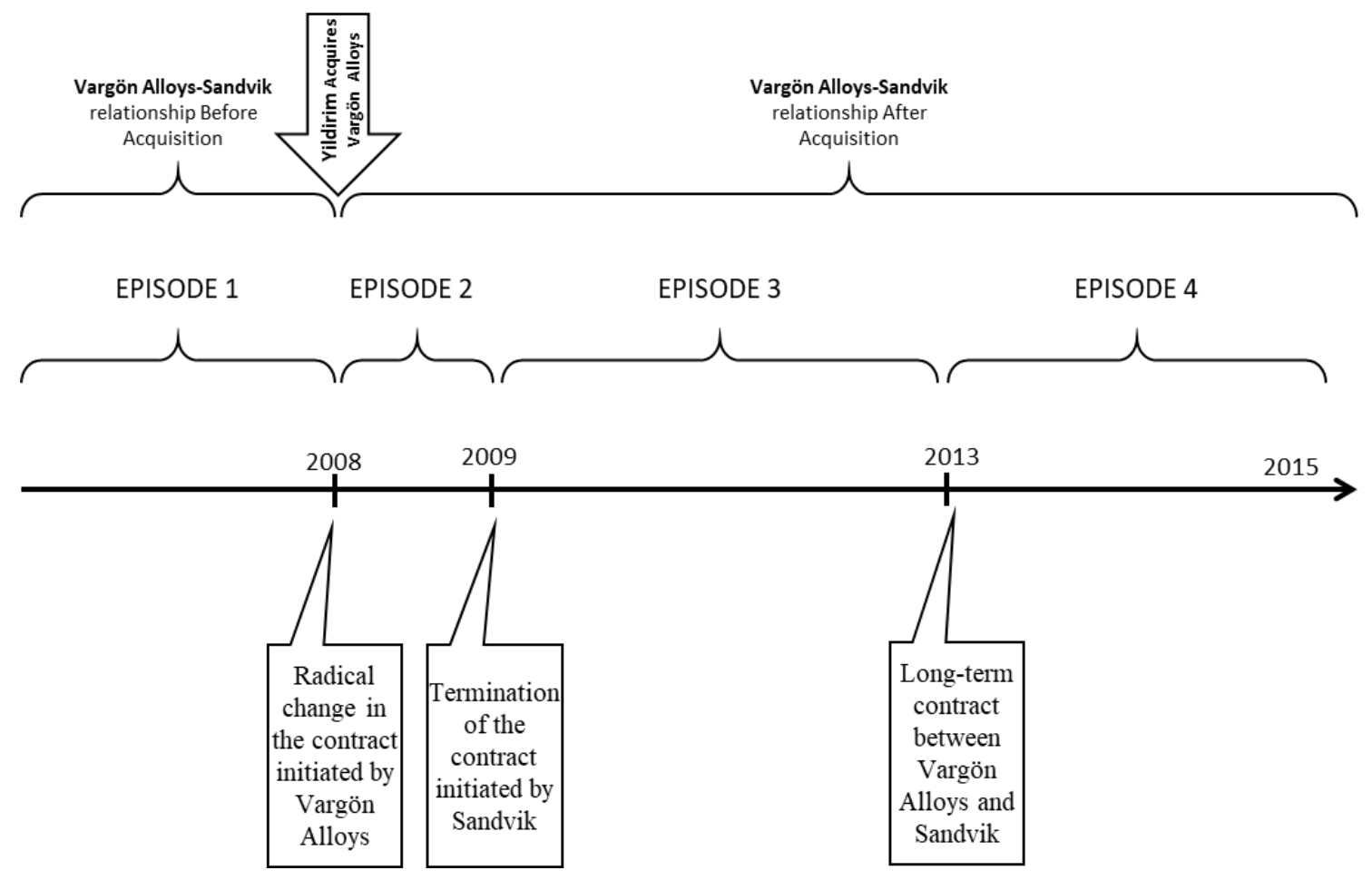
Relational arrangements

\begin{tabular}{|c|c|}
\hline$\neg$ & $\begin{array}{l}\text { - High degree of operational } \\
\text { and administrative } \\
\text { interdependencies } \\
\text { - Relational contracting } \\
\text { - Financial constraints (heavily } \\
\text { reliant on banks) }\end{array}$ \\
\hline & $\begin{array}{l}\text { - High degree of operational } \\
\text { and administrative } \\
\text { interdependencies } \\
\text { - Trust-based and informal } \\
\text { coordination mechanism } \\
\text { - Routinized logistics and } \\
\text { payment processes }\end{array}$ \\
\hline
\end{tabular}

\begin{tabular}{ll}
$\cdot \begin{array}{l}\text { No formal ties / termination } \\
\text { of contracts }\end{array}$ \\
$\cdot \begin{array}{l}\text { Occasional transaction by } \\
\text { using price as the mean of } \\
\text { communication } \\
\cdot \text { Replacement of } \\
\text { organizational trustworthiness } \\
\text { with personal trust }\end{array}$ \\
\hline$\frac{0}{2}$
\end{tabular}

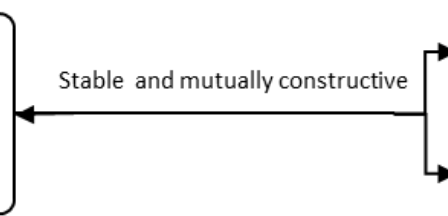

Parties' interests and goals

Buyer's goals
and interests

avoring long-term relational benefits

over favoring short-term gains.

Preferring trust-based, informa

coordination mechanism

Reification of relational arrangements

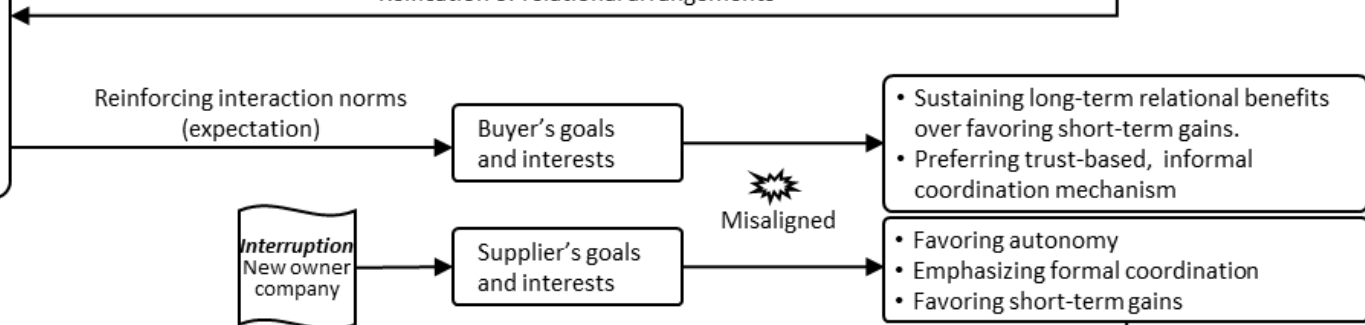

Deviation

Attempt to change-lack of constructive interaction
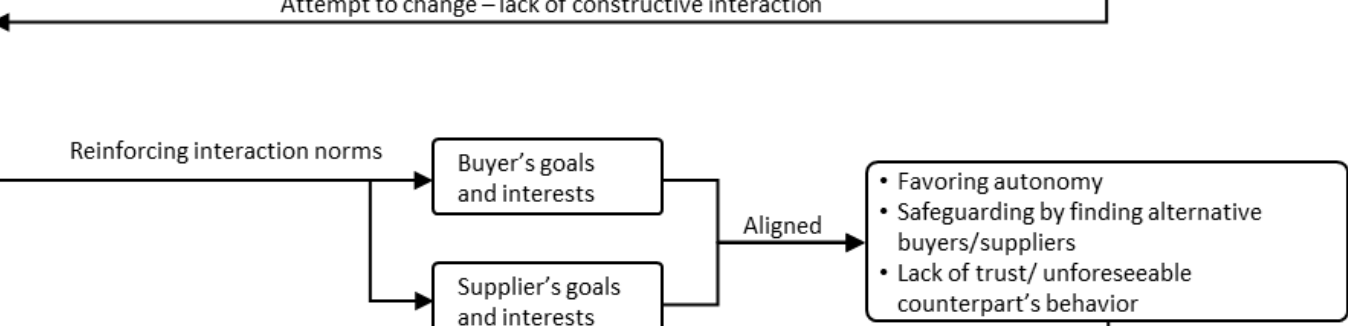

and interests

counterpart's behavior

Reification of relational arrangements

\begin{tabular}{|c|c|}
\hline $\begin{array}{l}+ \\
\frac{U}{0}\end{array}$ & $\begin{array}{l}\text { emergence of alternative } \\
\text { buyers/suppliers } \\
\text { - Short-term benefits are } \\
\text { highlighted while long-term } \\
\text { benefits are pursued by } \\
\text { caution } \\
\text { - Formal coordination } \\
\text { mechanism/ contracts }\end{array}$ \\
\hline
\end{tabular}

Figure 3 - Episodes of relationship construction, deconstruction and reconstruction 
Figure 4 - Revised framework - The process of relationship (re)construction

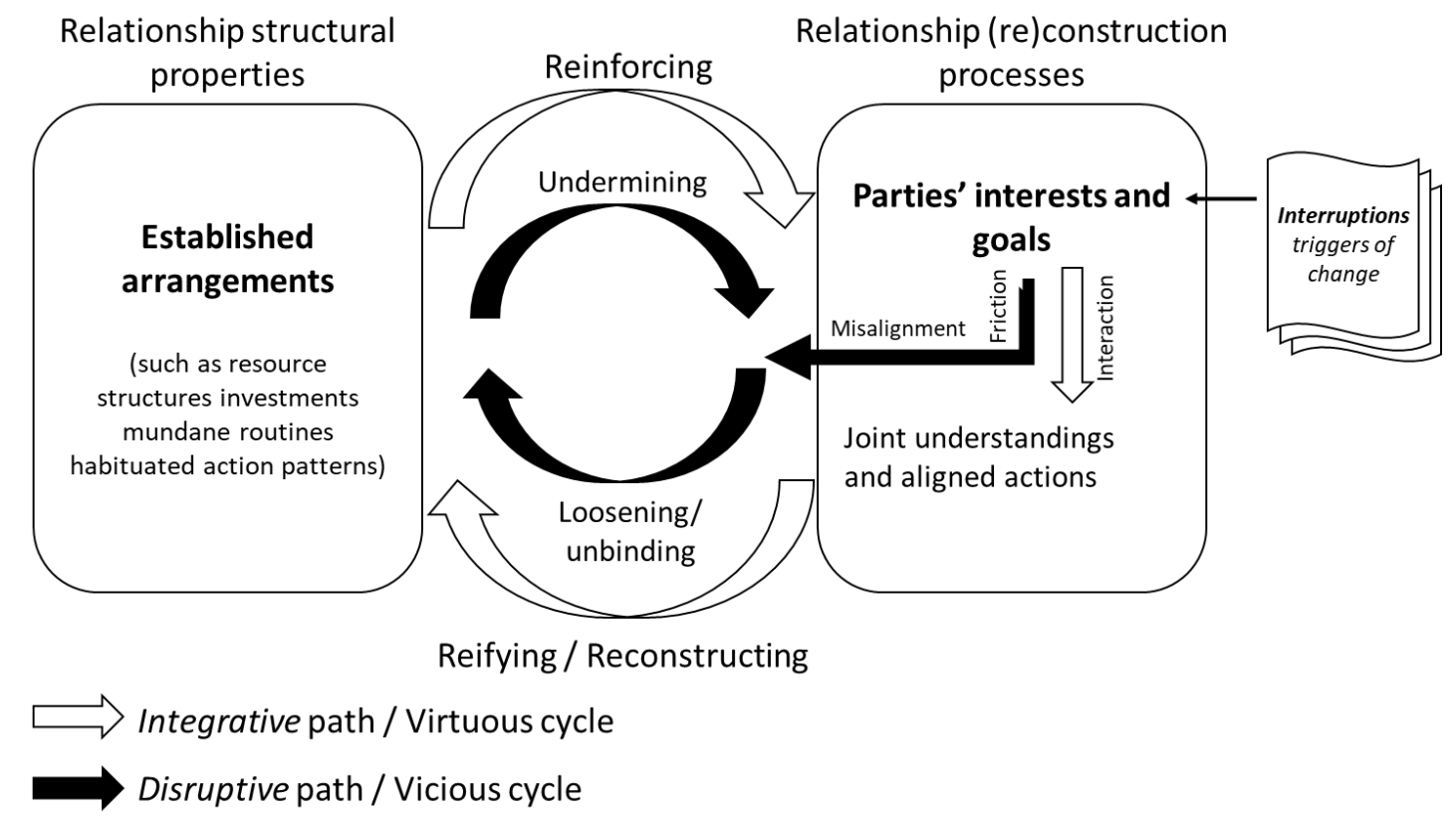

